\title{
Dobro publiczne w dobie alienacji
}

\section{Common welfare in the era of alienation}

\section{Streszczenie}

Praca koncentruje się wokół kondycji współczesnego społeczeństwa. Autor podejmuje próbę ocenienia potencjału drzemiącego w społecznościach i zdefiniowania istotnych aspektów dziedzin życia, które wpływają na postrzeganie przestrzeni. Mając świadomość, z jednej strony - kryzysu społeczeństwa, z drugiej zaś - ewolucji w kierunku coraz pełniejszej cywilizacji masowej, autor zgłębia problemy, które w Nowej Karcie Ateńskiej wyłącznie zarysowano. Poszukuje drogi do skutecznego planowania z udziałem wszystkich stron oraz wyjaśnia w jaki sposób pobudzić świadomość społecznej odpowiedzialności, przy użyciu odpowiednich kanałów komunikacji. W tym aspekcie wyszczególnione zostają sprawdzone w europejskich miastach sposoby, dzięki którym z sukcesem podjęto próby tworzenia pełnowartościowych przestrzeni publicznych.

Słowa kluczowe: partycypacja, społeczeństwo masowe, kanały komunikacji

\begin{abstract}
The essay focuses on the condition of modern society. The author tries to assess the potential hidden in communities and define important aspects of areas of life that affect the perception of space. The author, conscious of the crisis in society and evolution towards a mature mass civilization, tries to deeply analyse a few aspects which were only outlined in The New Charter of Athens. He looks for a way to plan effectively involving a majority of inhabitants. The author tries to explain how to stimulate awareness of social responsibility by the use of communication channels. He refers to the methods tried and tested in European cities which have been used in a process of designing valuable public spaces.
\end{abstract}

Keywords: participation, mass society, channels of communication 


\section{WSTĘP}

W starożytnej Grecji dom rodzinny był zwierciadłem gospodarza. Panowały w nim jasno określone zasady. Właściciel miał wyjątkową moc ustanawiania obiektów realnymi przez ujawnianie ich w przestrzeni publicznej; reszta była tylko cieniem rzeczywistości ${ }^{1}$. Podobnie sytuacja ma się w przypadku miast. Są one refleksem żyjących w nich ludzi. Wszystko, co publicznie konstytuują swymi rękoma, definiuje otoczenie. Im doskonalsze to dzieła, tym wspanialsze staje się miasto. Wszystkim więc powinno zależeć na budowaniu go w taki sposób, by życie w nim nie było uciążliwe i mogło bezpiecznie się rozwijać. Co jednak w przypadku, gdy zbiorowość interesów jest tak duża, iż zaczynają się wzajemnie wykluczać? Jak pobudzić partycypację na najniższych szczeblach w momencie, gdy społeczeństwo ulega dezintegracji, a mieszkańcy decydują się na świadomą alienację? Czym wobec tego staje się dziedzina publiczna, rzecz (z założenia) wspólna wszystkim użytkownikom?

\section{WIEK ZMIAN}

Runięcie Pruitt-Igoe w 1972 roku zamknęło epokę eksperymentów i wielkich ideologii. Stało się jasne, że ówczesna polityka odnowy miast przestała spełniać swoją rolę; dostrzeżono, że społeczeństwo nie mieści się już w modularnych podziałach narzuconych przez modernistycznych idealistów, wierzących, że strefowanie miast pozwoli rozwiązać problemy panującego chaosu (tak powszechnego u progu XX wieku).

\subsection{DWIE WIZJE MIAST}

Według pierwszej Karty Ateńskiej, projektowaniu przyświecać miała idea towarzysząca inżynierii maszyn. Wszystko, co wchodziło w skład miasta, miało być gruntownie przemyślane; najmniejsze elementy wchodziły w skład większych podzespołów, którym zlecano konkretne zadanie. Użytkownik miał tylko decydować o wyborze funkcji (mieszkanie/praca/ wypoczynek). Szybko jednak przekonano się, że mechaniczny porządek trafił w ręce żywiołu, który nie chciał podporządkować się schematyzacji.

W takiej sytuacji architekci i urbaniści stanęli przed szczególnym wyzwaniem. Jak bowiem stworzyć nową ideę planowania przestrzeni, przy jednoczesnym zachowaniu spuścizny Karty Ateńskiej z 1933 roku? Przez lata miasto przekształciło się w gąszcz interesów wielu grup społecznych. Ponadto, w wyniku upadku żelaznej kurtyny i stabilizacji na Starym Kontynencie, otworzyły się nowe perspektywy - polityczne i gospodarcze. Odpowiedzią na nowe wyzwania towarzyszące europejskiej integracji stała się w 1998 roku Nowa Karta Ateńska opracowana przez Europejską Radę Urbanistów². Zaproponowano w niej wizję miasta dla początku nowego tysiąclecia: 
Wizja nie jest ani nowq utopiq, ani oderwanq od realiów projekcjq innowacji technologicznej. Koncentruje się ona na Mieście Spójnym i jest wyobrażeniem takiego miasta, jakie chcielibyśmy mieć dziś i w przyszłości $i^{3}$.

Twórcy Karty upatrywali źródła problemów w braku spójności. To właśnie koherentne miasta, budowane w oparciu o troskę wobec tradycji, ekonomii, środowiska i społeczeństwa, miały pozwolić nie tylko na lokalny rozwój jednostek terytorialnych, ale również znormalizować je w taki sposób, by mogły łączyć się w policentryczne sieci. Po epoce wielkich projektantów, traktujących miasta jako inkubatory dla innowacji, nastał czas porządkowania i zszywania miejskich „wysp”. Czy jednak możliwe jest budowanie sieci metropolii w czasie, gdy najmniejsze komórki miast ulegają dekonstrukcji, a rozpiętości w poziomie warunków życia wciąż wzrastają?

\subsection{SPOŁECZNA SPÓJNOŚĆ}

Wyjątkowość Nowej Karty Ateńskiej polega na tym, iż po raz pierwszy zwrócono uwagę na złożoność procesu powstawania pełnowartościowej tkanki miejskiej. Oddolne ruchu społeczne dowiodły, że niemożliwe jest opracowanie planu na doskonałe miasto bez szerokiej analizy dotyczącej mieszkańców danego ośrodka. Do łask powróciły zagadnienia dziedzictwa i tożsamości. Obecnie szeroki program społeczny, koncentrujący się wokół siedmiu zagadnień ${ }^{5}$, jest odpowiedzią na nową rzeczywistość, w której system wolnorynkowy i globalizacja wytyczają kierunek cywilizacji, pociągając za sobą również szereg negatywnych procesów. Lekarstwem na to ma być zapewnienie ładu społecznego i wygody życia, ujęte w haśle równowagi i spójności społecznej ${ }^{6}$. Europejska Rada Urbanistów zwróciła szczególną uwagę na potrzebę tworzenia nowych systemów reprezentacji i partycypacji, które ułatwią dostęp do informacji publicznej i stworzą obszar współpracy z aktywnymi obywatelami. Ma to pozwolić na szerokie współuczestnictwo w wytyczaniu priorytetów dla miast. Skupiono się również na przemianach społecznych. Starzejące się społeczeństwo oraz obecność tzw. czasowych użytkowników miasta coraz częściej determinują decyzje planistów oraz władz samorządowych. Jak zauważają twórcy Karty: „[Istotnym] wyzwaniem jest unowocześnienie sposobów funkcjonowania demokracji lokalnej, poszukiwanie nowych dróg zwiększenia udziału społecznego i uczestnictwa wszystkich podmiotów w celu zabezpieczenia wspólnych interesów"7.

\subsection{NOWA KARTA ATEŃSKA A RZECZYWISTOŚĆ}

Łatwo ulec wrażeniu, że Karta kreuje wizję zielonych „miast z duszą”, w których świadome społeczeństwo potrafi troszczyć się o wspólne dobro. Jest to tylko jedna strona medalu. Dziedzina publiczna, szczególnie w Polsce, pozostaje w defensywie. Brak pomysłu na gospodarowanie dobrem miejskim powoduje, że przestrzeń ulega agresywnej prywatyzacji. Miasta coraz częściej przypominają ogromne przedsiębiorstwa, które, zmuszone konkurować 
o inwestycje, motywują swoje działania przez pryzmat finansów ${ }^{8}$. Przychylność zyskują ci, którzy oferują najwięcej, co powoduje, że lokalne potrzeby przestają mieć znaczenie. Wiara samorządu w społeczną korzyść płynącą z działalności sektora prywatnego spycha na dalszy plan ideę społecznego uczestnictwa. Temat uchybień demokracji znalazł miejsce w Nowej Karcie Ateńskiej i postrzegany jest jako efekt zmian politycznych w epoce wolnorynkowości.

Wizja miasta przyjaznego mieszkańcom, którzy dzięki swej aktywności będą w stanie zawalczyć o interes publiczny (nawet w obliczu intensyfikacji działań sektora prywatnego), może budzić wątpliwości. Wydaje się, że twórcy Nowej Karty Ateńskiej pokładają bezgraniczną ufność w jednostkę i jej zdolność do samoorganizacji. Obecnie jednak coraz trudniej wyobrazić sobie osiedla, które zrzeszają ludzi zdolnych do bezinteresownej integracji. Przeciwnie, coraz częściej mamy do czynienia ze świadomą alienacją, a jedność zachowują tylko te grupy, które potrafią jasno określić cel działania i interes - wymierny i osiągalny w krótkiej perspektywie czasowej. Kryzys napędzają lokalne samorządy, których działalność wpływa na ogólne niezadowolenie i poczucie osamotnienia w walce o interes publiczny.

\section{OBRAZ SPOLECZEŃSTWA}

Istotą wszelkich rozważań na temat społeczeństwa i jego zaangażowania w walkę o interes publiczny jest zbadanie kondycji ogółu populacji, na który niebagatelny wpływ miała nowożytność; odbiła się nie tylko na rozwoju, ale również na sposobie postrzegania rzeczywistości. Umieszczenie trosk ekonomicznych w centrum publicznej uwagi (pozostających dotychczas w domenie ogniska domowego) spowodowało zmianę nastawienia ludzi względem siebie; od tego momentu człowiek zaczął definiować się przez pryzmat konsumpcji. Doczesność, ze wszystkimi jej aspektami, osiągnęła nowy wymiar dzięki utożsamieniu się człowieka z naturą ludzką i jej ewolucyjnym charakterem.

\subsection{KLASYCZNE DZIEDZINY ŻYCIA}

Rozbicie uniwersalnej (do pewnego czasu) przestrzeni na relatywne światy przyczyniło się do destrukcji dwóch, dotychczas jasno zdefiniowanych obszarów - prywatnego i publicznego.

Oba terminy mocno zakorzenione są w europejskiej cywilizacji. Już w starożytnej Grecji występował wyraźny podział na dwie dziedziny życia. Rzymianie jeszcze mocniej je wyodrębnili, wytyczając między nimi konkretne granice ${ }^{10}$.

Kluczowe wydają się tu spostrzeżenia Hanny Arendt - wybitnej żydowskiej teoretyczki polityki, według której prywatność, w swoim deprywacyjnym charakterze, opiera się na nieobecności innych; wynika z „pozbawienia rzeczywistości, która bierze się z bycia widzianym i słyszanym przez innych"11. W założeniu jest to przestrzeń, która udziela schronienia przed światem i ścierającymi się w nim antagonizmami. Z drugiej strony otacza człowieka 
dziedzina publiczna, w której, według Arendt, zawierają się dwa zjawiska. Pierwsze odnosi się do powszechności odbioru bodźców - wszystko, co się w niej znajduje, „może być widziane i słyszane przez każdego i ma najszerszy z możliwych krąg odbiorców”12. To właśnie rzeczy poddane do ogólnego wglądu definiują rzeczywistość. Drugie zjawisko traktuje termin „publiczny”, jako określenie świata, który jest „wspólny wszystkim i różny od posiadanego w nim prywatnego miejsca"13. Odnosi się to nie tyle do pojęcia Ziemi i przyrody, a przestrzeni zdefiniowanej przez wytwory ludzkie - tak materiały jak i sprawy, w których się poruszamy. W świetle tego dziedzina publiczna powinna posiadać instrumenty do zespalania ludzi - zbierania ich w niejako jeden organizm. Tak zdefiniowane obszary, o określonych granicach, porządkowały rzeczywistość, a ich trwanie na zasadzie koegzystencji było podstawą budowania społeczeństwa wielu interesów o jasno określonych regułach.

\subsection{SPOŁECZEŃSTWO MASOWE}

Wraz z nastaniem nowożytności gruntownej przebudowie uległo społeczeństwo i jego systemy wartości ${ }^{14}$. Od tego momentu praca zepchnęła kontemplację (tak umiłowaną w starożytności i wiekach średnich) na niższe szczeble hierarchii ${ }^{15}$. Kapitał i praca stały się nowym punktem odniesienia, czego wyrazem były chociażby wielkie rewolucje XVIII i XIX wieku. To stworzyło niebezpieczeństwo utraty wspólnego dla wszystkich świata. Odkrycia tłumaczące umiejscowienie człowieka w niekończącym się wszechświecie zasiały wątpliwości. Rozczarowanie, jakiego bez wątpienia doświadczyły poprzednie pokolenia, zrodziło plon w postaci szerokiego relatywizmu. Widać to chociażby w powszechnym upadku pewników, który połączony ze świadomością, że twory ludzkie mają, podobnie jak autorzy, ograniczoną żywotność, doprowadził do ucieczki w siebie. Powstanie wielu różnorodnych „światów” złamało zasadę wspólnego wszystkim terytorium - Ziemi. Za Arendt można wnioskować, że reakcją obronną na bezwzględność czasu stała się próba zintensyfikowania uciech i konsumpcji rzeczy tego świata. Odstąpiono tym samym od przestrzeni publicznej, jako wspólnoty rzeczy gromadzących ludzi i wiążących ich ze sobą wzajemnie przez pryzmat trwałości. Doprowadziło to do zaprzeczenia definicji tak ważnej domeny, którą Arendt wyraziła słowami:

Jeżeli świat zawierać ma przestrzeń publicznq, nie można go budować dla jednego pokolenia i planować jedynie dla żyjqcych; musi on przekraczać czas życia śmiertelników ${ }^{16}$.

Permanentny brak pewności co do rzeczy tak dobrze znanych spowodowały wzrost nieufności już nie tylko do świata, ale także wobec żyjących wokół siebie ludzi. Potwierdziły to tragedie XX wieku. Dla świata i dziedziny publicznej, które przecież są zbiorem nieskończonej ilości perspektyw, zaczęto upatrywać miary, która byłaby w stanie objąć wszystkie aspekty życia człowieka. Zrodziło się to w zgodzie z odzywającą się potrzebą trwałości i pewności. Paradoksalnie, owym papierkiem lakmusowym stał się pieniądz (najmniej trwała z otaczających człowieka rzeczy) $)^{17}$. Zwężenie widzenia do jednego punktu zbiegu spowodowało, że 
„ludzie stali się osobami całkowicie prywatnymi, to znaczy zostali pozbawieni możliwości widzenia i słyszenia innych, bycia widzianym i słyszanym przez nich"18. Doprowadziło to do zatarcia się granic pomiędzy dziedziną prywatną i publiczną. Wdarcie się sfery quasi-publicznej do obszaru prywatnego zapoczątkowało proces „cofania się” ludzi do wnętrza, co zerwało „społeczną umowę" o współtworzeniu jednego, acz wieloaspektowe świata. Zaczęto postrzegać go w odmienny sposób - jako przestrzeń relacji „ja-oni”, z uwspólnionym dla wszystkich horyzontem. Zmarginalizował on potrzebę istnienia innych ludzi jako gwarantów rzeczywistości.

\subsection{ODPOWIEDŹ NA NOWY MODEL ZBIOROWOŚCI}

Postępujący rozwój społeczeństwa masowego odkrywa przed urbanistami i socjologami nowe wyzwania. Wzrost poziomu wiedzy na temat naszej planety przyczynił się do poszerzenia horyzontów świata na niespotykane dotąd rozmiary ${ }^{19}$. Ów pozytywny aspekt świadomości niesie ze sobą również negatywne konsekwencje. „Zmniejszenie” odległości między kontynentami (wzmocnione rozwojem technologii i cyfryzacji) skurczyło planetę do wielkości piłki golfowej20. Taki stan rzeczy uczynił z ludzi (ponownie, choć w zmienionej wersji) grupę nomadów. Możliwość bycia w każdym miejscu i o każdej porze pozbawił człowieka jego miejsca we wszechświecie. Zatarciu ulega świadomość symbiozy terytorium z prywatnym światem - w którym miejsce znajdują świętości, a czas ma subiektywny wymiar. Powód tej utraty jest prosty - zerwane zostały granice, które określały przestrzeń znaną i obcą, a co za tym idzie - sferę prywatną, w której można było skryć to, co człowiek uważał za ściśle związane z własnym „ja”.

Jaka powinna być odpowiedź na powszechną alienację społeczeństwa? Nie sposób udzielić jednoznacznej odpowiedzi. Trzeba zwrócić uwagę na „prędkość”, z jaką przychodzi ludzkości żyć. Coraz bardziej prawdopodobne staje się podejrzenie, że w trakcie istnienia jednego pokolenia ludzie będą ulegać znacznie większej liczbie trendów. To utrudnia planowanie z wyprzedzeniem w czasie. W tym wypadku pozostaje trwać w stałym skupieniu wobec śledzonych zjawisk.

Inną sprawą jest potrzeba odbudowania poczucia odpowiedzialności za przestrzeń. We wspólnym dla wszystkich świecie, otwartym na migracje, samorządowcy oraz planiści powinni różnymi środkami budować więź z mieszkańcami (zachowując szacunek wobec coraz silniejszej kosmopolitycznej tożsamości jednostek). To niezmiernie wymagające wyzwanie, gdyż przeciwstawia się pewnym cechom społeczeństwa masowego. Pierwszy krok do zmian opierać się powinien na określeniu relacji wobec Ziemi, gdyż mylne uznanie jej za rzecz przeznaczoną do „obrotu” prowadzi do skrajnego uprzedmiotowienia. W takiej sytuacji mądre i odpowiedzialne decyzje zawsze będą spychane na margines przez wspólny wszystkim punkt zbiegu - kapitał. 


\section{KANAŁY KOMUNIKACJI I ROZWIAZZANIA}

W społeczeństwie anonimowym i świadomie wyobcowanym trudno dojść do porozumienia. Wynika to nie tylko z mnogości interesów, ale również z braku oddolnego zaangażowania, przejawiającego się szeroką biernością, charakterystyczną dla tzw. społeczeństw zewnątrzsterownych ${ }^{21}$. Jak więc $w$ takim wypadku planować przestrzeń do życia, jeśli grono zainteresowanych partycypacją nie odzwierciedla pełnej struktury społeczności? Jak zachęcić mieszkańców do współpracy nad projektem?

\subsection{ANONIMOWOŚĆ A DOBRO WSPÓLNE}

Współcześnie człowiek wykazuje tendencje do tworzenia grup (często hermetycznych) o zdefiniowanym i łatwo dostrzegalnym interesie. Niejednokrotnie odpowiada to potrzebie budowania własnej rzeczywistości22 i dążeniu do szczęścia, czemu na drodze stoją odmienne punkty widzenia. Mnogość grup i interesów wymaga mediacji²3.

Dążenie miast do modelu przypominającego przedsiębiorstwo sprzyja budowaniu chłodnej relacji z mieszkańcami, która przyjmuje konsumpcyjny charakter ${ }^{24}$. Obywatele coraz częściej patrzą przez pryzmat powinności wobec aglomeracji i odbieranych z tego tytułu korzyści. Poszukiwanie regulacji prawnych dla większej aktywności miejskiej jest tylko częściowym rozwiązaniem. Podstawową ideą, która powinna przyświecać urzędnikom i planistom, jest wzmocnienie wśród mieszkańców poczucia jedności i odpowiedzialności za przestrzeń, otwierającej drogę do oddolnych inicjatyw, tak by możliwości społeczeństwa w odpowiedni sposób korespondowały z potencjałem urbanistycznym ${ }^{25}$.

Odpowiedzią na takie zapotrzebowanie może być budowa zdecentralizowanych jednostek, potrafiących analizować potrzeby mieszkańców z konkretnej perspektywy. Samorządy powinny wspierać organizacje społeczne, których działalność opierałaby się na promowaniu partycypacji obywatelskiej oraz gromadzeniu informacji na temat preferencji użytkowników miast. Tworzenie komórek w poszczególnych dzielnicach (o różnych formach działania) pozwoliłoby łatwiej wytyczać cele w rozwoju osiedli bądź dzielnic i zainteresowałoby tematem ludzi z różnych środowisk, którym często przyświecają przeciwne idee. Okresowe badania, opracowywane rokrocznie w formie sprawozdań, dałyby samorządowcom okazję do wglądu w sytuację dzielnic, co z pewnością przyczyniłoby się do skuteczniejszego gospodarowania wspólnym majątkiem. Ich działalność nie opierałaby się wyłącznie na opracowywaniu statystyk, lecz przede wszystkim na organizacji wydarzeń (warsztatów, dyskusji, gier miejskich) pochylających się nad konkretnymi zagadnieniami. Wsparłoby to kształtowanie się poczucia odpowiedzialności za to, co nas otacza, zachęciło lokalne społeczności do angażowaniu się w życie miasta, a przez to dało podwaliny pod odnajdywanie własnego miejsca na świecie. 


\subsection{WSPÓLNY WYSItEK}

Na szczególną uwagę zasługują inicjatywy, które zyskują popularność w wielu europejskich miastach i sprawdzają się w procesach mających na celu wypracowanie porozumienia między inwestorami a mieszkańcami. Warto przytoczyć przykład Warsztatów Charette - inicjatywy rozpowszechnionej w USA, po którą sięga coraz więcej krajów Unii Europejskiej. Metoda polega na zebraniu w jednym miejscu jak największej liczby zainteresowanych osób - ekspertów, inwestorów oraz mieszkańców. Zadaniem spotkania ${ }^{26}$ jest rozwiązanie problemów związanych z opracowywanym terenem, a co za tym idzie, stworzenie projektu, odpowiadającego na potrzeby wszystkich użytkowników. Zgodnie z zasadami, uczestnicy zostają podzieleni na mniejsze grupy, w zależności od liczby zagadnień. Moderowane rozmowy pozwalają wypracować konkretne propozycje, którymi dyskutujący dzielą się systematycznie z pozostałymi grupami. Wieloetapowe rozmowy pozwalają zgłębić większość aspektów i poznać zdanie różnych środowisk.

Innymi rozwiązaniami, działającymi często na mniejszą skalę, są chociażby komórki planujące i zespoły robocze. Pierwsze z nich proponuje rozwiązanie dotyczące zdecentralizowanych instytucji w formie „barometru nastrojów społecznych”. Projekt polega na stworzeniu grupy 25 osób, której członkowie przez określony czas spełniają rolę lokalnych konsultantów, zbierających informacje na temat opracowywanego zagadnienia. Czuwa nad nimi grupa moderatorów, odpowiadających za przebieg inicjatywy. Seria spotkań z mieszkańcami i ekspertami pozwala sporządzić „obywatelski raport”, który następnie przekazuje się władzom samorządowym. Inicjatywa jest szczególnie pomocna w przypadkach, gdy pojawiają się trudności projektowe, które należy skonsultować z obywatelami.

Druga metoda (grupy robocze) odnosi się do przypadków, kiedy podjęcie decyzji wymaga pochylenia się przedstawicieli różnych środowisk nad opracowanym przez ekspertów raportem. W tym przypadku tworzy się zespół (10-30 osób), skupiający ludzi z różnych grup społecznych - od urzędników po niezrzeszonych obywateli. Może mieć charakter czasowy bądź stały i przyjmować różne role, a jego głównym zadaniem jest stworzenie konkretnego projektu w procesie opartym na szeregu dyskusji. Ostateczny wynik przekazywany jest władzom samorządowym. Taki model pracy ułatwia wymianę doświadczenia pomiędzy ekspertami i członkami lokalnych społeczności ${ }^{27}$.

\subsection{URBAN COMMONS}

Zdarza się, że inicjatywy partycypacyjne pełnią wyłącznie rolę opiniotwórczą, a lokalne władze uznają wypracowane ustalenia za cenne sugestie, które i tak nie znajdują odzwierciedlenia w rzeczywistości. Dopiero ważne dla wszystkich kwestie potrafią wywołać poruszenie, które ma szansę wpłynąć na decyzje samorządowców. Dowodem na to jest projekt ws. prywatyzacji sieci włoskich wodociągów, który rozpętał publiczną debatę na temat objęcia 
ochroną wody - jako dobra publicznego. To rozszerzyło dyskusję na ogólne zagadnienie „dobra wspólnego" (urban commons). Stworzona definicja mówi o „zasobach należących do wszystkich udziałowców społecznych, które prawo musi chronić, również dla przyszłych pokoleń"28. Nie ma wątpliwości, że tak zdefiniowane elementy mają wielką wartość dla większości społeczeństwa. Dzięki temu o wiele łatwiej jest działać w tym obszarze, tak aktywistom, jak i urzędnikom.

Jedne z pierwszych kroków w dziedzinie urban commons podjęła Rada Miasta Bolonii w 2014 roku, przyjmując rozporządzenie w sprawie współpracy między obywatelami a administracją publiczną. Dotyczyło ono działań „mających na celu opiekę i regenerację miejskich dóbr publicznych (commons)"29. Stworzyło to ogólne ramy prawne do oddolnych inicjatyw, według których obywatele mieliby zgłaszać własne projekty z ofertą wkładu własnego pod postacią wolontariatu. Decyzja ta odnosiła się głównie do projektów o tzw. niskim progu konfliktu ${ }^{30}$.

Podobną drogą podążył Neapol, którego Rada Miejska już w 2013 roku przyjęła Kartę Przestrzeni Publicznej; ustalenia odnosiły się do procedur wspierania przestrzeni publicznej w mieście. Rok później zatwierdzono rozporządzenie ws. urban commons, które „wspiera logikę samorządności i eksperymentalnego zarządzania przestrzeniami publicznymi”31. Efektem tego jest inicjatywa Je So'Pazzo, w wyniku której grupa mieszkańców przejęła przestrzeń byłego szpitalu psychiatrycznego i zorganizowała w nim usługi dla lokalnej społeczności. Umowa z gminą stanowi, że koszty komunalne pokrywają władze miasta, zaś wydatki związane z działalnością leżą w gestii użytkowników².

Analogiczne rozwiązania stają się coraz bardziej popularne w pozostałych krajach Unii Europejskiej. O te działania zabiegają nie tylko mieszkańcy, ale również lokalne administracje, które coraz chętniej przyłączają się do sieci samorządów wspierających partycypacyjne zarządzanie.

\section{PODSUMOWANIE}

Wzrost indywidualizmu człowieka i odsunięcie zagrożeń nietrywialnych poza linię horyzontu przyczyniły się do osłabienia więzi pomiędzy mieszkańcami. Kryzys w rodzinach przeniósł się na wyższe szczeble zbiorowości. Łatwo ulec wrażeniu, że życie zależy znacznie bardziej od przedsiębiorcy po drugiej stronie globu niż kogoś mieszkającego po przeciwnej stronie ulicy. Globalna wioska napędza poczucie osamotnienia, któremu lokalne władze w żadne sposób nie przeciwdziałają. Miasta, traktowane jako przedsiębiorstwa, przyjmują charakter usługowy, przez co nie stwarzają dobrej atmosfery do życia. Jednym ze środków zaradczych, zdolnych stanąć w opozycji do kryzysu, jest próba odbudowania tożsamości miast jako obszarów zamieszkiwanych przez ludzi, których aspiracje wyrażają się we wzroście metropolii. Jest to szczególne wyzwanie dla władz samorządowych, które we właściwy 
sposób powinny reagować na potrzeby mieszkańców, zachowując przy tym pole dla inwestycji sektora prywatnego. Wierząc w ideę decentralizacji i zrównoważonego rozwoju, urzędnicy powinni zacieśniać współpracę z organizacjami pożytku publicznego, które najlepiej odzwierciedlają nastroje społeczne. Okazji do dialogu jest wiele, o czym świadczy szeroki zakres narzędzi komunikacji. Wymienione w publikacji warsztaty Charette, komórki planujące czy zespoły robocze są tylko częścią „pakietów pomocy” przydatnych w procesie planowania i konsultacji. Powyższe metody zdobyły szerokie uznanie w wielu krajach Europy, dzięki czemu wspólnym wysiłkiem zabezpieczono tak ważne, z punktu widzenia społeczeństwa, interesy publiczne - czy to przywracając do życia miejsca budujące tożsamość obywateli, czy zabezpieczając prawnie oddolne inicjatywy.

Kluczowe w tym wszystkim jest odkrycie wspólnotowości i wielowymiarowości zbiorowego życia. Należy pamiętać, że „koniec wspólnego świata nadchodzi wówczas, gdy świat ten jest widziany tylko $\mathrm{w}$ jednym aspekcie i wolno mu prezentować się tylko w jednej perspektywie"33.

\section{PRZYPISY}

1 Na podstawie wniosków H. Arendt, Kondycja ludzka, Wydawnictwo Aletheia, Warszawa 2010.

2 Uzupełniona w 2003 roku.

3 Nowa Karta Ateńska. Wizja miast XXI wieku, oprac. Europejska Rada Urbanistów, tłum. S. Wyganowski, Lizbona 2003, 6.

4 „Dekonstrukcja najmniejszych komórek miast” objawia się brakiem holistycznego spojrzenia na miasto - nie jako związku osiedli, lecz „administracyjnej unii” enklaw. W tym wypadku przedstawicielom dzielnic nierzadko pozostaje walka o wyłącznie lokalny interes, co tylko napędza rozkład miejskiej wspólnoty. $Z$ drugiej strony rozpad objawia się (a zarazem napędza) wzrostem „rozpiętości w poziomie warunków życia”. Polaryzacja zachodzi szczególnie w rejonach, w których odtrąca się istniejącą tkankę - napływowa ludność (mniej lub bardziej świadomie) ogradza się od „rdzennych” mieszkańców, tworząc niejako zamożne wyspy.

5 Twórcy Nowej Karty Ateńskiej w rozdziale „Spójność społeczna” wyszczególnili siedem zagadnień, na które urbaniści powinni zwracać szczególną uwagę: równowaga społeczna, zaangażowanie społeczne, wielokulturowe bogactwo, związki międzypokoleniowe, tożsamość społeczna, ruchliwość i środki transportu, usługi. Wszystkie z nich odzwierciedliły rzeczywiste tendencje mieszkańców miast.

6 Nowa Karta Ateńska. Wizja miast XXI wieku, op. cit., 7.

7 Ibidem, 17.

8 Zjawisko „prywatyzacji miast” zostało wskazane w Nowej Karcie Ateńskiej jako jedna z tendencji zmian (Europejska Rada Urbanistów, op. cit., 15).

9 Rozważania na temat nowożytności: H. Arendt, Kondycja ludzka, op. cit. 
$10 \mathrm{O}$ istotnym znaczeniu obu dziedzin świadczy m.in. mnogość bóstw opiekujących się daną sferą.

${ }^{11} \mathrm{H}$. Arendt, Kondycja ludzka, op. cit., s. 79.

12 Ibidem, s. 70.

13 Ibidem, s. 73.

${ }^{14}$ Według Arendt, przyczyniło się to również do podmiany podstawowych pytań - miejsce "co?" i „dlaczego?” zajęło „jak?”.

15 A z nią szeroko pojętej idei, koncentrującej się wokół zagadnień, które z obecnego, praktycznego punktu widzenia wydają się bezużyteczne ze względu na niemożność ocenienia ich ekonomicznej wartości.

${ }^{16}$ H. Arendt, Kondycja ludzka, op. cit., s. 75.

17 Dowodzą temu wnioski H. Arendt.

${ }^{18}$ H. Arendt, Kondycja ludzka, op. cit., s. 78.

${ }^{19}$ Wg Arendt „wytyczenie” Archimedejskiego punktu oparcia poza globem rzuciło całkiem nowe światło na ludzkość i planetę.

${ }^{20}$ Z przekorą można stwierdzić, że pierwszym etapem poznania świata jest postawienie go na szafce $w$ dziecięcym pokoju.

${ }^{21}$ W temacie kultury masowej, zob.: D. Riesman, Samotny tłum, Państwowe Wydawnictwo Naukowe, Warszawa 1971.

22 Odpowiadającej elementom składowym wewnętrznego świata.

${ }^{23}$ Według Nowej Karty Ateńskiej niedocenionym aspektem pracy planisty jest właśnie mediacja i szukanie konsensusu.

24 „Miasta-przedsiębiorstwa” sprzyjają zanikaniu zbiorowego poczucia odpowiedzialności. To również prowadzi do kurczenia się domeny publicznej i zanikania „wielkiej narracji miejskiej” (K. Frysztacki, Między przestrzeniq i publicznościq miejskq, [w:] Przemiany miasta. Wokół socjologii Aleksandra Wallisa, red. B. Jałowiecki, A. Majera, M.S. Szczepański, Wydawnictwo Naukowe Scholar, Warszawa 2005, s. 153).

25 S. Lose, Ku urbanologii. Didaskalia architektury i urbanistyki, Wydawnictwo Unpubleashed, Wrocław 2015, s. 25-28.

${ }^{26}$ Może trwać kilka godzin bądź kilka dni - wówczas dzieli się je na kilka sesji.

${ }^{27}$ Więcej informacji na temat partycypacji obywatelskiej na stronie: http://partycypacjaobywatelska.pl/strefa-wiedzy/techniki.

${ }^{28}$ Cyt. za: D. Patti, Przestrzeń jako dobro wspólne w mieście. Przykłady włoskich regulacji, Autoportret, 2017, nr 3 [58], s. 81.

${ }^{29}$ Ibidem, s. 83.

30 Projekty o niskim progu konfliktu to inicjatywy, które nie ingerują w problematyczne zagadnienia sfery społeczno-politycznej (własność, zarządzanie i warunki ekonomiczne nieruchomości); w świetle tego bolońskie inicjatywy dotyczą głównie otwartych przestrzeni publicznych o przejrzystym statucie własnościowym.

${ }^{31}$ D. Patti, Przestrzeń jako dobro wspólne w mieście, op. cit., s. 84. 
32 Ibidem, 84.

${ }^{33}$ H. Arendt, Kondycja ludzka, op. cit., 79.

\section{BIBLIOGRAFIA}

Arendt H., Kondycja ludzka, Wydawnictwo Aletheia, Warszawa 2010.

Frysztacki K., Między przestrzeniq i publicznościq miejskq, [w:] Przemiany miasta. Wokół socjologii Aleksandra Wallisa, red. B. Jałowiecki, A. Majera, M.S. Szczepański, Wydawnictwo Naukowe Scholar, Warszawa 2005, 151-158.

Lose S., Ku urbanologii. Didaskalia architektury i urbanistyki, Wydawnictwo Unpubleashed, Wrocław 2015.

Nowa Karta Ateńska. Wizja miast XXI wieku, oprac. Europejska Rada Urbanistów, tłum. S. Wyganowski, Lizbona 2003.

Patti D., Przestrzeń jako dobro wspólne w mieście. Przykłady włoskich regulacji, Autoportret, 2017, nr 3 [58], 81-85.

Riesman D., Samotny tłum, Państwowe Wydawnictwo Naukowe, Warszawa 1971.

Archirama.pl, https://archirama.muratorplus.pl/architektura/39-lat-po-smierci-architektury-modernizmu,67_1094.html (dostęp: 22.03.2018).

Partycypacja obywatelska - komórki planujqce, http://partycypacjaobywatelska.pl/strefa-wiedzy/techniki/komorki-planujace/ (dostęp: 25.03.2018).

Partycypacja obywatelska - Warsztaty Charette, http://partycypacjaobywatelska.pl/strefa-wiedzy/techniki/charette/ (dostęp: 24.03.2018).

Partycypacja obywatelska - zespół roboczy, http://partycypacjaobywatelska.pl/strefa-wiedzy/ techniki/zespol-roboczy-grupa-robocza/ (dostęp: 25.03.2018).

Urbnews.pl, http://urbnews.pl/warsztaty-charette-otoczenie-dopasowane-mieszkancow/ (dostęp: 24.03.2018).

ADRES BIBLIOGRAFICZNY ARTYKU ŁU: Rodak M., Dobro publiczne w dobie alienacji, Przestrzeń/Urbanistyka/Architektura, 1/2018, S. 285-296.

DATA AKCEPTACJI OSTATECZNEJ WERSII DO OPUBLIKOWANIA: 17.06.2018. 